\title{
Finding a Common Cause: Fourth-Century Greek Discourses on Rulership
}

\section{Introduction: The Unexpected Christian Ruler}

No Christian or pagan would have expected, hoped, or feared that a Roman emperor who served as a pagan priest would become a Christian. Could anyone have anticipated that an emperor, often revered as a god, might tear down the very foundations of his rule? As a result, no specific Christian concept of rulership existed when Constantine did the unexpected and turned to the Christian God. Under those circumstances, nobody could easily define what it meant to be a Christian emperor. ${ }^{1}$

Christian concepts of Roman rulership drew on two sources. The first was the Hebrew Bible, which Christians appropriated as their Old Testament. Its historical books depicted many cruel, obstinate foreign rulers who fought against God's chosen people. But there were also many Israelite rulers who did not listen to God's commands; such famous kings as David and Solomon were shown in their sinfulness. Not even Josiah, who was perhaps closest to perfection, stayed free from errors. The prophetic books were full of criticism of Jewish kings as well, who regularly deviated from the way of God. How a pious ruler was expected to behave could be seen ex negativo. Moses represented another type of ruler who did not bear the title of a king but was a prophet and even acted as a lawgiver in the name of God; yet, not even his record was stainless. ${ }^{2}$ Apart from the narrative books, the so-called "royal psalms" included verses of praise for good rulership in the tradition of ancient Mesopotamian kingdoms. Nevertheless, the deeply embedded idea, especially in the prophetic tradition, that a ruler could err and should listen to advisers who spoke in the name of God in order to avoid sinful behaviour became an important element in the concept of Christian rulership.

A second source of Christian concepts of Roman rulership could have been Fürstenspiegel (mirrors of princes). Educated Christians were aware of the tradition of the Graeco-Roman Fürstenspiegel, which went as far back as Isocrates in the fourth century BCE. Such texts defined the virtues expected of a ruler. Thousands of panegyrics must have been recited for multiple occasions all over the Hellenistic and Roman empires year after year, if not more often. They followed certain rules laid down in rhetorical textbooks and normally avoided any open criticism of the emperor. Menander Rhetor's (third c. CE) textbooks on epideictic speeches suggest the form most panegyrics must have taken. Nonetheless, it would be misleading to interpret

1 See the introduction to this volume.

2 Andreas Lehnardt, Mose I. In: RAC 25 (2013) 58-102.

2 OpenAccess. (C) 2021 Hartmut Leppin, published by De Gruyter. (cc) BY-NC-ND This work is licensed under the Creative Commons Attribution-NonCommercial-NoDerivatives 4.0 International License. 
the panegyrics as mere flattery; the public ascription of certain virtues could also have an adhortative function. Lacunae could be meaningful if, for example, a subject of praise recommended in the handbooks was circumnavigated. ${ }^{3}$

Some Christian apologies addressed to the Roman emperors offered words of praise in the panegyric tradition, but they were not specifically Christian. Justin, for example, extolled Marc Aurelius and Lucius Verus for their interest in education, not without distinguishing nicely between the two. ${ }^{4}$ But a specific Christian concept of imperial praise did not emerge during the first centuries.

Thus, when Constantine the Great professed that he wanted to show his gratitude to the Christian God after his God-given victory in the Battle of the Milvian Bridge in 312, he confronted his panegyrists with a formidable task: How should they praise a Christian emperor ${ }^{5}$ They had grown up in a tradition of praise that glorified the god-like qualities of the emperors. This was based on a concept of divinity that made no clear distinction between gods and men. Men could become heroes, emperors were revered as gods, and they expected to be deified after their death. Christian theology, by contrast, held that only one man, Jesus, was both God and man - even if the dispute about the two natures of Christ was to disrupt the churches for centuries.

Elites remained divided about religion. Some members of the traditional elites were Christians, some pagans. Some Christians were more consistent than others, and the same was true for pagans. ${ }^{6}$ In addition, bishops formed a new elite that felt entitled to praise and (even more so) to criticise the emperor.

At least three discourses of imperial praise developed in the fourth century Roman Empire: the hierocratic discourse, which eulogised the sacral position of the ruler in a Christian sense, the neutralising discourse that avoided religious commitments and often employed ambiguous language, and the penitentiary discourse, which accepted and sublimated the sinfulness of the emperor in a Christian sense. ${ }^{7}$ These distinctions are mainly heuristic but may help to map the field. I will expound

3 Gunnar Seelentag, Taten und Tugenden Traians: Herrschaftsdarstellung im Principat (Hermes. Einzelschriften 91), Stuttgart 2004.

4 Iust., apol. 1.1. The words on Lucius Verus have been expunged by Volkmar and Markovich in their editions. But this passage is also attested in Euseb., hist. eccl. 4.12.

5 See the introduction to this volume.

6 Alan Cameron, The Last Pagans of Rome, Oxford/New York 2011.

7 Hartmut Leppin, Kaisertum und Christentum in der Spätantike: Überlegungen zu einer unwahrscheinlichen Synthese. In: A. Fahrmeir and A. Imhausen (ed.), Die Vielfalt normativer Ordnungen. Konflikte und Dynamik in historischer und ethnologischer Perspektive (Normative Orders 8), Frankfurt am Main 2013, 197-223, 211-214. In this contribution I distinguished between a Christocentric, a penitentiary, and a hierocratic discourse, which I have slightly modified here. Although I criticise him on some points, the best overview on late antique political thinking is still Francis Dvornik, Early Christian and Byzantine Political Philosophy: Origins and Background 2 (DOS 9), Washington, D.C. 1966, 610 - 850. For some observations on Eusebius, see Gilbert Dagron, Emperor and Priest: The Imperial Office in Byzantium, Cambridge 2003, 131-135. 
on sacralising discourses in the second section and on neutralising discourses in the third, using a few examples from imperial panegyrics. Mikhail Boytsov and Kai Preuß explore penitentiary discourses more deeply in their contributions to this volume.

\section{The Perils of Hierocratic Discourses: Eusebian Models}

Eusebius of Caesarea (264/5 - 339/40) was a provincial, if well-educated, bishop from Palestine who claimed to be a confidant of Constantine. There is no doubt that the two men met on various occasions, but it is not clear whether Eusebius was as close to the emperor as he suggests. Although certainly not the official voice of Constantinian propaganda, he was an important voice, especially for later generations. And, for pragmatic reasons, he could not deviate too much from Constantine's official position. Therefore, he is a significant source for how Christian orators navigated the role of the emperor after Constantine inaugurated a tradition of imperial support for and the promotion of Christianity. He also embodies an important development in the social history of imperial praise. Traditionally, the individuals authorised to express a public judgement about living emperors were philosophers and rhetoricians who claimed parrhesia to also criticise them; historians felt entitled to judge only deceased emperors. Eusebius, however, is a bishop who commented on the emperor both during his lifetime and after his death. ${ }^{8}$ He was familiar with the technical expressions for Roman rulers, but, following the tradition of the panegyrics, he normally uses the word $\beta \alpha \sigma \iota \lambda \varepsilon u ́ \varsigma$ with some exceptions where he prefers graecised Latin expressions for the sake of clarity. ${ }^{9}$

Three of his works reveal how Eusebius reacted to the Constantinian challenge: The Historia ecclesiastica, the final version of which was probably published in its present form in about $323,{ }^{10}$ the Laudes Constantini of 336 and his Vita Constantini, which was published after Constantine's death.

\footnotetext{
8 Still foundational is Raffaele Farina, L'impero e l'imperatore cristiano in Eusebio di Cesarea: La prima teologia politica del Cristianesimo, Zurich 1966, who, however, underlines much more the unity of Eusebius's concept than I intend to in this contribution. Cf. Dvornik (cf. fn. 7) 614-622. Martin Wallraff, Eusebs Konstantin. Geschichte, Theologie und keine Geschichtstheologie? In: Delgado, Mariano (ed.): Gott in der Geschichte: Zum Ringen um das Verständnis von Heil und Unheil in der Geschichte des Christentums. Fribourg/Stuttgart 2013, 85-98 warns against reading the texts with a predominantly theological perspective.

9 E. g. Euseb., hist. eccl. 2.23.1; Euseb., vita Const. 1.1.3;1.18.1; 1.22.2; 3.43.4. It goes without saying that the Latin titles appear in the official documents quoted by Eusebius in his Historia ecclesiastica. 10 For an introduction to the work, see Sébastien Morlet and Lorenzo Perrone, Eusèbe de Césarée, Histoire ecclésiastique. Commentaire I. Études d'introduction, Paris 2012. More recently, see V. Bradley Lewis, Eusebius of Caesarea's Unplatonic Platonic Political Theology. In: Polis. Journal for Ancient Greek Political Thought 34 (2017) 94-114.
} 
The final version of the last three books in Eusebius' Historia ecclesiastica ${ }^{11}$ describe the history of his own age. The eighth book graphically depicts Diocletian's and Galerius' persecutions, ${ }^{12}$ the ninth hails the triumphs over the two persecutors (in Eusebius' eyes) Maxentius and Maximinus Daia, and the tenth praises the new rule and the final victory of Constantius, who is bringing about an age of peace. After some brief mentions, Constantine is formally introduced when he intervenes in the civil wars, and Eusebius makes his role clear immediately: he is elected by God, the son of a ruler, and a pious man (9.9.1) - piety is the only virtue mentioned at this stage.

Eusebius strongly highlights the legitimacy of the ruler because Constantine's acclamation as emperor directly contradicted the system of the tetrarchy, which did not envisage hereditary succession. In the course of the narration, Constantine shows mercy ( $\left.\varphi \varepsilon ı \delta \omega^{\prime}\right)$ to the inhabitants of Rome under tyrannical rule - a good reason to fight for their old freedom, we are expected to believe. Maxentius perishes like Pharaoh (9.9.5-8). This parallel likens Constantine to Moses, who was perceived as an ideal leader by early Christians. ${ }^{13} \mathrm{He}$ is received by the senate and the people of

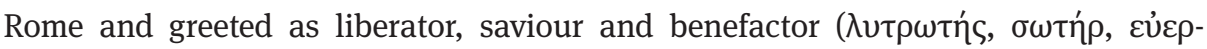

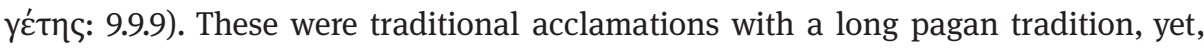
they must have reminded Christians of Christ, especially the title $\sigma \omega \tau \eta \dot{\rho}$ (saviour).

In his narrative, Eusebius praises Constantine on the basis of Roman traditions highlighting the senate's role and Roman liberty (a motive also present in contemporaneous panegyrics and on his coins) along with biblical references. Eusebius takes for granted that both traditions converge easily although Christianity prevails. Constantine shows no arrogance attributing his success to Christ alone. Consequently, he issues legislation in favour of the Christians (9.9.10-12).

The tenth book begins with a prayer of thanksgiving. Furthermore, it celebrates the reestablishment of the churches and the building of new churches, especially the

11 For the stages of the genesis of the books and their meanings, see Valerio Neri, Les éditions de l'Histoire ecclésiastique (livres VIII-IX). Bilan critique et perspectives de la recherché. In: Morlet and Perrone (cf. fn. 10) 151-183; Matthieu Cassin, Muriel Debié and Michel-Yves Perrin, La question des editions de l'Histoire ecclésiastique et le livre X, ibid. 185-207. Most recently, see Patrick Andrist, La dernière édition Eusébienne del'Histoire Ecclésiastique: Une nouvelle proposition. In: Scriptorium 69 (2015) 217-235.

12 This is also described in Eusebius' De martyribus Palaestinae.

13 Bernd Isele, Moses oder Pharao? Die ersten christlichen Kaiser und das Argument der Bibel. In: Andreas Pečar and Kai Trampedach (ed.), Die Bibel als politisches Argument. Voraussetzungen und Folgen biblizistischer Herrschaftslegitimation in der Vormoderne (HZ Beihefte 43), Munich 2007, $103-$ 118. Finn Damgaard, Propaganda against Propaganda: Revisiting Eusebius' Use of the Figure of Moses in the Life of Constantine. In: Aaron Johnson and Jeremy Schott (ed.), Eusebius of Caesarea. Tradition and Innovations (Hellenic Studies 60), Cambridge MA 2013, 115-132; Lehnardt (cf. fn. 2) $89-100$. 
church of Tyre (see the unusually long chapter 10.4), ${ }^{14}$ reproduces various pro-Christian imperial laws and reports the final victory over Licinius who wages war against all Christians (a passage, which Eusebius added in his final revision after praising Licinius as a worthy partner of Constantine in previous versions). The final paragraphs celebrate Constantine as victor, God-fearing, and the creator of a unified empire full of splendour that he rules with laws full of philanthropy. The last sentences of the Historia ecclesiastica indicate the spirit that shapes the passages on Constantine:

There were promulgated in every place ordinances of the victorious emperor full of love for humanity, and laws that showed munificence and true piety. Thus verily, when all tyranny had been purged away, the kingdom that belonged to them, was preserved steadfast and undisputed for Constantine and his sons alone; who, when they had made their very first action to cleanse the world from the hatred of God, conscious of the good things that He had bestowed upon them, displayed their love of virtue and of God, their piety and gratitude towards the Deity, by their manifest deeds in the sight of all men. ${ }^{15}$

Constantine, as characterised in the Historia ecclesiastica, is first and foremost a pious and, consequently, successful ruler. This continues the tradition of classical concepts of good rulership. But justice, which is so important elsewhere, has no prominent position here; instead, the emperor creates a situation in which everybody (or rather, every Christian) can lead a life of spiritual fulfilment. Eusebius' Constantine fosters the Christian church by every means available. The bishop does not offer a reflection on the limits of rulers as human beings; instead, the reader has the chance to contemplate the materialisation of a perfect world (although he learns that Satan is always looking at it invidiously). The reader will find no distinctively Christian virtues, but Eusebius uses the instrument of typology to illustrate Constantine's role in the salvific history of Christianity.

\footnotetext{
14 On this passage, an oration of Eusebius on the dedication of the cathedral of Tyre, see Jeremy M. Schott, Eusebius' Panegyric on the Building of Churches (Euseb., hist. eccl. 10.4.2-72): Aesthetics and the Politics of Christian Architecture. In: Sabrina Inowlocki and Claudio Zamagni (ed.), Reconsidering Eusebius. Collected Papers on Literary, Historical, and Theological Issues (Supplements to Vigiliae Christianae 107), Leiden/Boston 2011, 177-197.

15 "Н

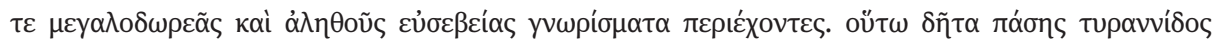

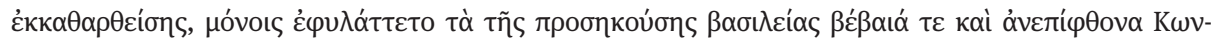

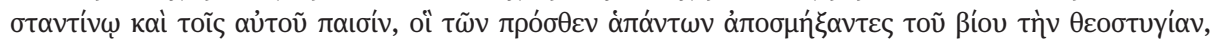

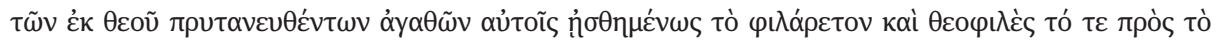

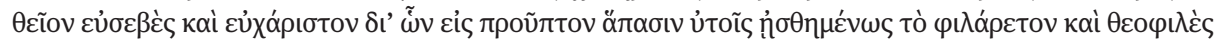

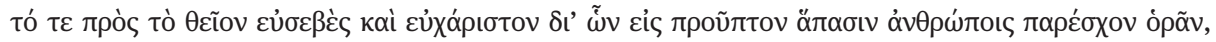

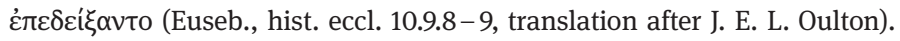


The Laudes Constantini pay tribute to the thirtieth anniversary of Constantine's rule celebrated on July 25, 336 - which highlighted the unusual length of his reign. ${ }^{16}$ They betray the rhetorical tradition of the panegyrics and do not completely avoid allusions to classical mythology (Praef. 1. 2). ${ }^{17}$ But in contrasting himself to other rhetoricians, Eusebius uses his status as a cleric to offer something different, as he claims, a spiritual dimension that focuses on the godlike virtues and pious acts of the emperor. In fact, he sets out to demonstrate how theology and imperial representation can be reconciled with one another. He thus starts by praising God while at the same time embedding Constantine in the cosmological order, in which God's Logos acts through the emperor. Constantine is dear $(\varphi \text { í } \lambda \circ)^{18}$ to God and changes the world in order to make it worthy of God.

He who is dear to Him, like some interpreter of the Logos of God, summons the whole human race to knowledge of the Higher Power, calling in a great voice that all can hear and proclaiming for everyone on earth the laws of genuine piety. ${ }^{19}$

Constantine does not adorn the jubilee with pagan sacrifices; his sacrifices are his own person and his subjects (2.5). He appears like a priest and is even called icpo-

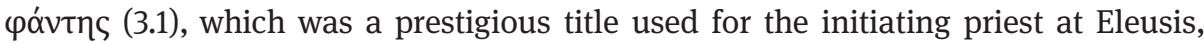
Roman pontifices or Jewish High Priests (LSJ 823). Both Christ-Logos and Constantine

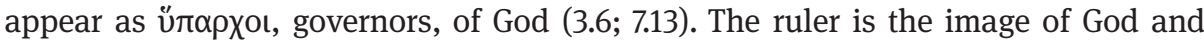
imitates the Logos-Christ at the same time. ${ }^{20}$ The concept of correspondence between

16 The second part of the text as it is edited now is often quoted as LC 11-18. I follow Drake in quoting it as SC (De sepulchro Christi), but for pragmatic reasons I start with ch. 11. For the background, see Hal A. Drake, In Praise of Constantine. A Historical Study and New Translation of Eusebias' Tricennial Orations, Berkeley/Los Angeles 1976, 30 - 45. Drake argues that SC was delivered in 335 in Jerusalem (42f.). Contra Pierre Maraval, Introduction. In: Id. (ed.), Eusèbe de Césarée, La théologie politique de l'empire chrétien: Louanges de Constantin (triakontaétérikos), Paris 2001, 29-34 argues that the speech was given in Constantinople which seems more probable. For the philosophical background apart from the rich study of Farina 1966 and the two translations quoted, see Dominic J. O'Meara, Platonopolis. Platonic Political Philosophy in Late Antiquity, Oxford 2003, 145-151. For ideological background, see Johannes Wienand, Der Kaiser als Sieger. Metamorphosen triumphaler Herrschaft unter Constantin I. (Klio Beiheft 19), Berlin 2012, 421-437.

17 For the mocking of classical education, see SC 11.4.

18 Drake translates friend (see his note 1 on p. 158); yet it seems obvious that Eusebius wants to evoke the word $\theta \varepsilon$ ó $\varphi$ ı

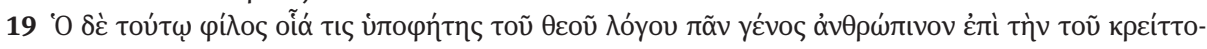

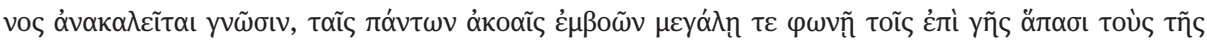

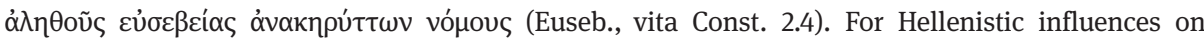
this passage, see Drake (cf. fn. 16) 158, n. 4.

20 For the theological background, see Winfried Löhr, Logos. In: RAC 23 (2010) 327-435, at 406-411. For scepticism under theological aspects, see Alois Grillmeier, Jesus der Christus im Glauben der Kirche I, 3rd ed., Freiburg 1979, 300 -326. For underlining the inventive character of Eusebius' work, see Devin Singh, Eusebius as Political Theologian: The Legend Continues. In: HThR 108 (2015) 129-154; especially $139-152$. 
earthly rule and cosmic order, as well as the idea that a good man and good ruler can become similar to God dates back to Plato (e.g., resp. 10, 613a/b; leg. 4, 715e-716d). Eusebius demonstrated that is was possible to rearticulate this idea in a Christian way, which then allowed Themistius to neutralise the concept, making it acceptable both to pagans and Christians.

Eusebius establishes an intimate connection between piety and the reign's duration, the reliable order of succession, and the divinely inspired rule over the whole world (3.1-4); indeed, no Roman Emperor after Augustus had reigned for as long a period as Constantine. The monarchy on earth mirrors the heavenly order and is justified in this way (3.5-6). From the orator's perspective, the whole political system has become sacralised even under an eschatological perspective (3.2 with Dan 7:18).

The emperor's Platonic virtues such as wisdom, goodness, justness and prudence are presented as evidence of his connection with God (5). His mastery of the passions proves that he is a true ruler, which even earns him the title of philosopher-king (5.4). He knows of the precariousness of his reign and prays to God night and day (5.5). Furthermore, he despises the customary symbols and resources of power (5.6f.). After narrating the salvific history of mankind, Eusebius describes Constantine as elected by God to put an end to persecutions and to become the ruler of the whole world, converting the barbarians to Christianity. He suppresses outrageous pagan cults $(8-9.8)$ and remains true to the Christian faith, erecting churches $(9.8-19)$. He is a teacher of the true faith to his soldiers (9.9f.). Constantine has "found in Him the Saviour and Guardian of his house, his kingdom and his line." ${ }^{21}$ Eusebius ascribes to him an immediate connection with God. He is the "interpreter of the All-Ruling God" (10.4). ${ }^{22}$ There is no need for clerical intervention. Military success does not play an important role here: ${ }^{23}$ Eusebius belonged to nonmilitary elites who could not have doubted the necessity of military successes for imperial representation but show an interest in placing non-military achievements in the foreground. It is therefore not necessary to assume that this mirrors a change in the imperial representation as such.

The Laudes Constantini have, as it seems, been transmitted together with another very similar work, the Oration on the Holy Sepulchre in Jerusalem. Although the problem of kingship is not discussed extensively in the latter, the same idea of the relationship between God, Logos and emperor prevails. Thanks to providence, the Mediterranean world is united when Christianity emerges, and victory is granted to Constantine (16). The saviour approaches him during sleep (18.3) as he had done before the battle at the Milvian Bridge. He duly praises Constantine as the donator of the church and defends his church buildings against pagan detractors (11.2-4).

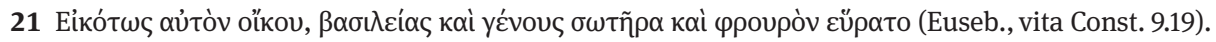

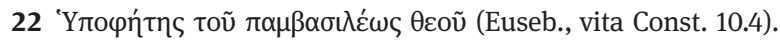

23 Noel Lenski, Constantine and the Cities: Imperial Authority and Civic Politics Cities, Pennsylvania 2016, 44. 
Although many passages mirror ideas of ancient philosophy, especially Platonic and Stoic concepts, the image of the good ruler given by Eusebius is fundamentally new. In the Laudes Constantini, the emperor appears as an embodiment of Christian virtue who, like the Logos, mediates between heaven and earth. He imitates God's rule and does not depend on the advice of any cleric whose role is reduced to defining the emperor's position adequately. Christ's suffering is conspicuously absent from this oration. Theological reasons might be invoked to explain this omission or the wish to present an understandable and purely monotheistic religion, ${ }^{24}$ but in doing so Eusebius also eschewed any commitment regarding the theological controversies that raged at this time.

In his classic article, Norman H. Baynes defined this text as shaped by Hellenistic traditions and fundamental to Byzantine imperial ideology, in the sense that the existence of one true God meant that there could be only one true ruler on earth. ${ }^{25}$ Baynes' description probably presupposes a much too homogeneous idea of Byzantine imperial ideology. In any case, Eusebius was obviously not very influential among his contemporaries or in the next generations of the late antique empire. $^{26}$ The next generations of Christians who knew Christian emperors would often view them as heretics; the experience of conflicts and exiles redefined the role of the emperor. Although there was no doubt that the emperor was ordained by God, his personal, human weaknesses were highlighted, which made it much more difficult to identify him with Christ.

Eusebius composed the so-called Vita Constantini (which had, to a greater extent, the character of an encomium) after the emperor's death; it is already more guarded than his previous works with respect to a Christocentric interpretation of Constantine's role. ${ }^{27}$ From the onset, Eusebius makes clear that Constantine is an emperor beloved by God. He draws a strong connection between the emperor's Christian belief and his successes. Constantine is moved to opt for the Christian God by his observation that this God has, in contrast to others, given victory to his father Constantius I (1.27.3). He appears as an exemplary Christian emperor:

This is... what God whom Constantine honoured, by standing helpfully at Constantine's side at the beginning, the middle and the end of his reign, confirmed by his manifest judgement, putting forward this man as a lesson for the fear of God to the human race. As the only one of the widely renowned emperors of all time whom God set up as a huge luminary and loud-voiced

24 Drake (cf. fn. 16) 47-58.

25 Norman H. Baynes, Eusebius and the Christian Empire. In: Mélanges Bidez 1934, $13-18$ = Id., Byzantine Studies and Other Essays, London 1955, 168-172.

26 The low number of manuscripts is highlighted in Wallraff (cf. fn. 8) 89f. The Laudes have only been transmitted together with some manuscripts of the Vita.

27 For commentary, see Averil Cameron and Stuart G. Hall (ed.), Eusebius. Life of Constantine. Introduction, Translation, and Commentary, Oxford 1999 and the excellent Einführung by Bruno Bleckmann, Eusebius of Caesarea, De Vita Constantini. Über das Leben Konstantins (Fontes Christiani 83), Turnhout 2007, 7-106. 
herald of unerring fear of God, he is the only one to whom God gave convincing proofs of his fear of God by the benefits of every kind which were accorded to him: He honoured his imperial reign with three complete decades, and circumscribed his human life with twice that number. Making

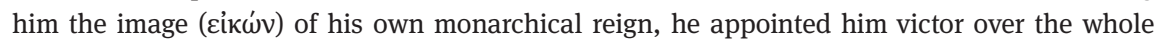
race of tyrants and destroyer of the God-battling giants, who in mental frenzy raised weapons against the Sovereign of the universe himself. ${ }^{28}$

$\Theta \varepsilon o \sigma \varepsilon ́ \beta \varepsilon ı \alpha$ is defined here as Constantine's central virtue. Standard dictionaries translate the word as fear of God, worship of God, religiousness and the like. In Christian contexts it can simply mean right belief or Christianity; ${ }^{29}$ in any case, it is clearly different from the idea of similarity to God.

Eusebius' work has a roughly chronological structure. The first two books describe Constantine's triumphant way to sole rule. The third and fourth books feature his achievements as a ruler and the well-being of his subjects while the last chapters of the fourth book describe his death and his burial in detail. Consequently, Eusebius does not enumerate Constantine's virtues and merits systematically and does not even always name them explicitly; instead, he often dedicates entire chapters or a group of chapters to individual deeds that evoke certain virtues which are then hinted at or evoked again or made explicit in passages elsewhere in the Vita. In the following, I attempt to systematise the ideas in this seemingly uneven work.

Eusebius' Constantine perfectly embodies the traditional virtues of a ruler. He is a successful general who conquers the whole world (1.46). As a young man, he is excellent in body and soul even arousing envy (1.19f.). His body remains strong and healthy throughout his life (4.53).

The young man ascends his throne as his father's legitimate successor (1.21f.) and is at the same time chosen by God (1.24). He proves to be victorious against domestic enemies and against barbarians, often by peaceful means and on a civilising mission. ${ }^{30}$ He cares for justice, exemplified by his passing laws and dispensing justice (4.2f.), and displays generosity (1.9). He cares for the poor and for orphans, be they Christians or not (1.43). Philanthropy is the pinnacle of his virtues (4.54).

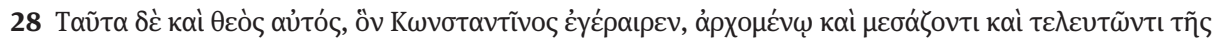

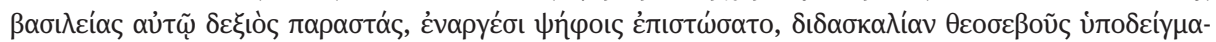

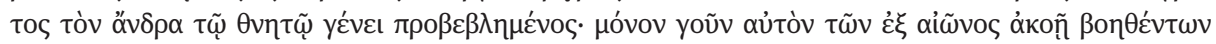

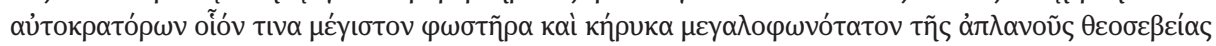

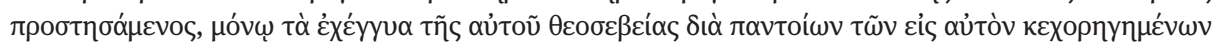

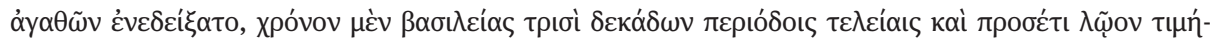

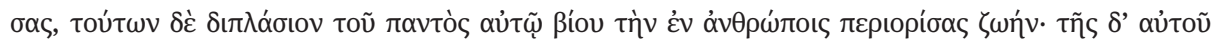

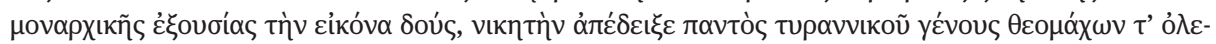

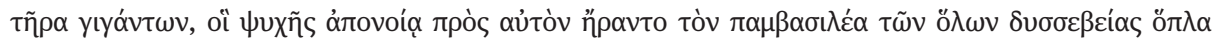
(Euseb., vita Const. 1.4-5.1, translation according to Cameron and Hall [cf. fn. 27]).

29 See, e.g., Lampe, 634f. Averil Cameron and Stuart Hall's translation of $\theta \varepsilon o \sigma \varepsilon ́ \beta \varepsilon เ \alpha$ et sim. with godliness, however, is misleading.
}

30 Euseb., vita Const. 1.8; 1.25; 4.5-14; 4.50. 
God's grace becomes evident in Constantine's having three sons as co-rulers and successors (4.40) and his ability to be their instructor in the art of ruling (4.52).

In the panegyric fashion, Eusebius evokes exemplary rulers of the past: Cyrus the Persian and Alexander the Macedonian (1.7). Yet, Eusebius' Constantine goes far beyond the pagan model; his peaceful death at an advanced age evidences how God loves him in contrast to them (1.6f.).

Eusebius' general tendency in his Vita is to show that Constantine has outperformed non-Christian rulers in respect to traditional virtues such as courage, mildness, munificence or wise legislation because he believes in the true God and follows his laws. Clarifying that their heroes surpass all the previous rulers was a time-tested technique of panegyrists, but Eusebius accentuates this in a special way: Constantine surpasses any ruler because he believes in God. Thus, he compares Constantine not only to classical models of rulership, but again to Moses in various aspects.

In comparison to the Historia ecclesiastica, the Vita Constantini interprets Moses much more as a typos of Constantine. Moses had lived as a hostage of a tyrant as Constantine did at Diocletian's court and became a liberator of his people (1.12; 1.19.1; cf. 1.39.2). Both had to flee the court (1.20.2). But he is equal to Moses even as a military leader: he defeats Maxentius in the same manner as Moses beat Pharaoh (1.38.2-39.1). He behaves like Moses during the war against Licinius whereas his enemy is obdurate like Pharaoh (2.11f.). ${ }^{31}$ In an image unique to this work, Constantine even appears like an angel during his dazzling adventus to the Council of Nicaea (3.10.3).

Eusebius specifies deeds that are characteristic for a Christian ruler: his Constantine suppresses pagan cults. ${ }^{32}$ In Eusebius's depiction, Palestine is emblematic for Constantine's anti-pagan measures, especially his purge of the place where the Church of the Holy Sepulchre was to be built (3.62.5) and of Mamre (3.52-53). He favours Christianity and Christians wherever possible issuing laws to this intent and writing letters that teach and help Christians. ${ }^{33}$ He grants privileges to clerics, builds churches in Jerusalem, Constantinople, Nicomedia, Antioch and in other places $(1.42,2 ; 3.29-53)$, and he has holy books distributed to the churches. He furthers the churches economically, which also entails helping the poor (4.44.2; 4.28). His Christian attitude is even visible in his foreign policy, as he acts as a protector of Persian Christians (4.8-13).

On the occasion of his vicennalia, Constantine distributes donations across his empire. But this jubilee is also connected with the Council of Nicaea, which Eusebius

31 On the assimilation of Moses to Christ, see Euseb., dem. evang. 3.2.1-30; Lehnardt (cf. fn 2) 93-95. For Moses in the Praeparatio and Demonstratio, see Sabrina Inowlocki, Eusebius' Appropriation of Moses in an Apologetic Context. In: Axel Graupner and Michael Wolter (ed.), Moses in Biblical and Extra-Biblical Traditions (Beihefte zur Zeitschrift für die alttestamentliche Wissenschaft 372), Berlin/New York 2007, 241-255.

32 Euseb., vita Const. 2.23-61.1; 3.54-58; 4.23; 25.

33 Euseb., vita Const. 3.24; 4.18-20; 4.34. 
describes in all its splendour, and thus has an ecclesiastical aspect (3.22). He pays respect to clerics, even if they look shabby in their attire, and wants to be surrounded by them (1.42.1; cf. 2.4.1); he knows that their prayers can help him (4.14) and shows a keen interest in a sermon of Eusebius (4.33), which might even astonish modern readers.

As a Christian emperor, Constantine faces new and difficult challenges such as the never-ending quarrels among Christians. Eusebius repeatedly mentions his efforts to reconcile rival Christian groups and to establish peace within the church. ${ }^{34}$ The climax is the Council of Nicaea, where he leaves no doubt that the emperor is the leading figure on this occasion (3.6-23; for the emperor especially 3.12f.). In general, Constantine energetically fights heresies (3.63-66). But he cannot ignore the fact that disputes continued to torment Christians and makes envy responsible for them, which has its origins in Satan. ${ }^{35}$

Constantine's achievements are deeply connected with certain virtues: he leads a holy, pure life, again in imitation of Moses (2.12.1), but also in accordance with Christian ethics $(2.14 ; 4.22)$.

Although Eusebius glorifies Constantine extensively, he also adopts the semantics of humility:

As a loyal and good servant, he would perform this and announce it, openly calling himself a slave and confessing himself a servant of the All-sovereign, while God in recompense was close at hand to make him Lord and Despot, the only Victor among the Emperors of all time to remain irresistible and unconquered.... ${ }^{36}$

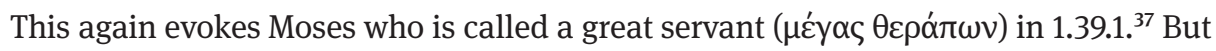
it also reminds Christian readers of the servant of God in Deutero-Isaiah, which they interpreted as a prophecy regarding Jesus Christ. Another virtue is parrhesia, the old catchword of the Athenian democracy, which in a Christian context means the frank

34 Euseb., vita Const. 1.44; 2.61.2; 3.59f.; 4.41-47.

35 Euseb., vita Const. 2.61.3; 2.73.1; 3.1.1; 3.59.1; 4.41.1.

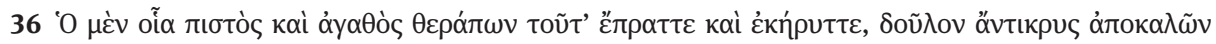

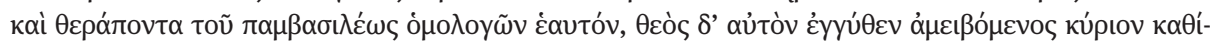

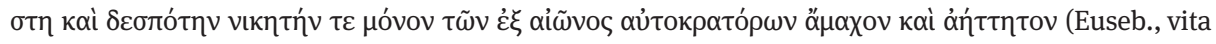
Const. 1.6) - the chapter continues this way; cf. 1.3.1.

37 The same word is in Euseb., hist. eccl. 1.2.6; 9.9.8. For humility as a self-designation, see Euseb., vita Const. 1.5.2; 1.47.2; 2.55.1; 3.5.2; 4.14.1. 2.71.4. For humility for other servants of God such as clerics,

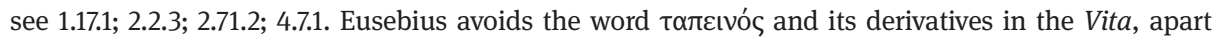

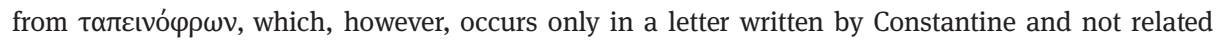
to his own person (4.10.3). For passages that accentuate the limits of human life in Eusebius, see Farina 1966, $220 \mathrm{f}$. I do not think that this is specific enough to be interpreted as an expression of humility. 
confession of trusting in God and therefore speaking freely before him and any worldly authority. ${ }^{38}$

The virtue of philanthropy, mentioned above, automatically carries Christian connotations in Eusebius' works (2.20.1). The emperor shows mildness towards his enemies in war (2.13). Eusebius could have derived this from within the tradition of Roman thought in the sense of Caesarian clementia, but he frames it in a Christian way.

This means that Eusebius' Constantine is not only the Roman emperor par excellence but also embodies all the different Christian roles. The virtue of parrhesia brings him close to martyrs and other defenders of Christian confessors, teachers, prophets and bishops. Humility is an elite Christian virtue highly distinctive from traditional ideas that put honour centre stage.

Despite his ostensible respect for clerics, Constantine has his own relationship with God, not only praying himself (4.22), but also reading the Holy Scripture (4.17). Fittingly, he receives visions from God not only before the battle of the Milvian Bridge. ${ }^{39}$ As a good orator (4.55), he does not shy away from teaching theology $(4.29-31)$.

It comes as no surprise that Constantine is depicted as an almost perfect emperor. Eusebius goes so far as to compare him with the sun because of his manifold

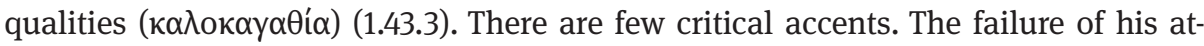
tempts to reconcile Christians is implied in the narration. Speaking about philanthropy, Eusebius concedes that the emperor could have been misled by it to trust deceivers (4.54.3). But these are rare exceptions.

Perfection sounds boring. Nevertheless, it is important to look at what remains unsaid. In contrast to the earlier texts, the Vita Constantini does not provide an eschatological perspective and the character of sacralisation is different. Eusebius compares Constantine to Moses and to an angel, but not to Christ or the Logos. On the other hand, the aspect of humility is more prominent. There is no single Eusebian concept of monarchy; rather, it changes in the course of his works. The image of Constantine was to become a crucial feature of the idea of good Christian rulers, as can be seen in many contributions of this volume, but their viewpoints seem to have been mainly influenced by his Historia ecclesiastica and by other idealising traditions about Constantine rather than by Eusebius' most nuanced work, the Vita Constantini (which then was used by the so-called synoptical Greek church historians).

Although there is not one unitary concept of the good Christian ruler in Eusebius' works, Constantine appears throughout the three texts discussed so far as a man in direct contact with God and receiving his own visions. ${ }^{40}$ Although he

38 Euseb., vita Const. 1.8.4; 1.41.1; 3.2.2. To read it in another context (a letter of Constantine), see 1.32.2.

39 Euseb., vita Const. 1.28; 2.12.2; 3.3.3; 3.25.

40 This was a central element of Constantine's self-representation. See Lenski (cf. fn. 23) 56-60 who underlines that this idea was familiar to pagans. 
shows respect to clerics, he does not depend on them. The well-known parallel between monarchy and monotheism also turns up in the Vita Constantini:

And he, famous for every virtue of God-fearing, the Emperor Victor (he created this title personally for himself as his most appropriate surname because of the victory God had given him over all his enemies and foes) $)^{41}$ took over the east. He brought under his control one Roman Empire united as of old, the first to proclaim to all the monarchy of God, and by the monarchy himself directing the whole of life under Roman rule. ${ }^{42}$

With all his pious language, Eusebius is aware of the limits of this concept. Constantine rebukes a cleric who says that he will reign alongside the Son of God:

When all these things were being done by the Emperor, and his great valour on God's behalf was being praised by the mouths of all, one of God's ministers in an excess of boldness declared in his presence that he was "Blessed," because in this present life he had been judged worthy of universal imperial power, and in the next he would rule alongside the son of God. He was annoyed on hearing these words, and told him he should not say such rash things, but should rather pray for him, that in both his life and the next he might be found worthy to be God's slave. ${ }^{43}$

This is also a clear theological message. The Laudes Constantini could be read in the sense that Constantine was a second Christ. This is the idea the cleric expresses who went too far according to Eusebius' Constantine. It must have been in the air at this time, but Eusebius clearly rejects it in his text that is primarily directed at Constantine's sons.

Eusebius' depiction of the perfect, successful, and modest Christian ruler Constantine in his so-called Vita Constantini attests to his imaginative power. The traditional role of the emperor is not supplanted, but enlarged by his Christian commitments, which, however, are more important since they are decisive for the wellbeing of the world. In contrast to the Laudes Constantini, the emperor is not assimilated to Christ and the Logos; instead, he is a loyal servant, which implies an attitude of humility towards God.

41 S. Wienand (cf. fn. 16) 486.

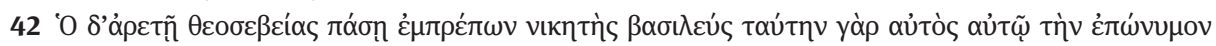

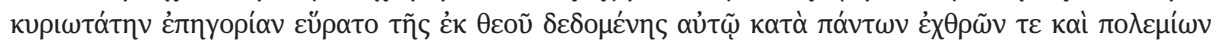

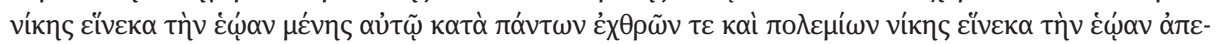

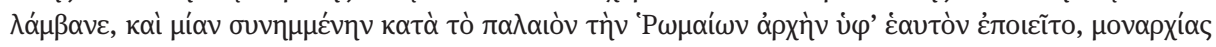

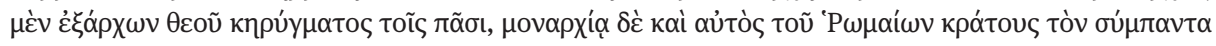

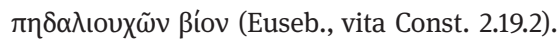

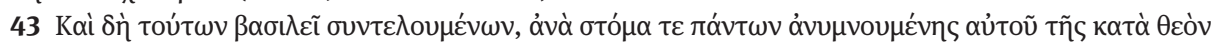

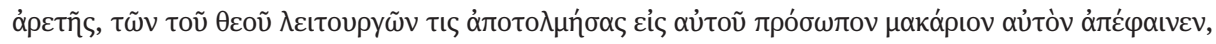

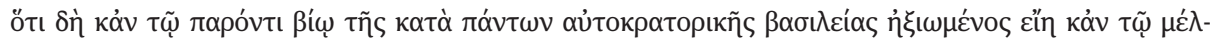

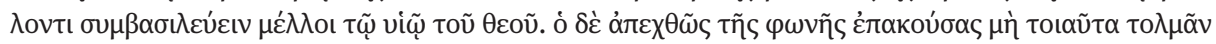

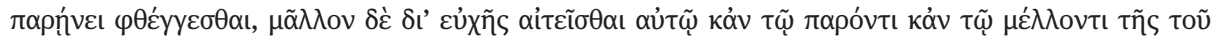

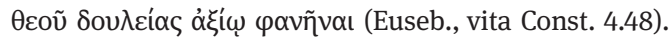


It is easy to see that Eusebius' depiction of Constantine not only idealises him but is meant to be a stylisation of Constantine's rule (which was perfectly legitimate in this genre of writing). ${ }^{44}$

Eusebius tries to eschew the question of Constantine's doubtful legitimacy within the tetrarchic system that conceded no privileged position to the natural sons of tetrarchs. Eusebius does not mention Hannibalianus and Dalmatius, both of whom had an important role in Constantine's plans for his succession but were murdered on the order of his sons who are duly praised as rightful rulers (1.1.3). Eusebius must have been aware of the accusations against Constantine that included debauchery or murder within his own family, which are documented in the works of Zosimus and even of the church historian Sozomen..$^{45}$ But he does not deem it necessary to refute them.

In his Laudes Constantini, Eusebius brilliantly developed a Christocentric discourse of rule - whether on the behest of Constantine or not remains unclear. Yet, his Vita Constantini already shows its limits. The following generations of Christians discussed the question of the sacral character of the emperor under various aspects. Was he a superhuman being? Should he be defined as a priest? What could his role be in church? ${ }^{46}$ Hierocratic discourses grew in importance especially during the sixth and seventh centuries. Justinian (r. 527-565) staged himself as a holy man, but also acknowledged his own sinfulness. Both Christian discourses came together in this case. ${ }^{47}$ George of Pisidia attributed Christ-like qualities to Heraclius (r. 610-641). When he helps his soldiers during a ship-wreck, light emanating from Heraclius reminds Christian readers of the transfiguration of Jesus as described in the synoptic gospels; like Jesus in Gethsemane, he loses sweat while praying. ${ }^{48}$ The hierocratic discourses were extremely influential, but they existed in multifarious variations.

44 In another study, I have discussed how Eusebius, in the same work, frames Constantine's actions through his description of his palace: Hartmut Leppin, Zwischen Kirche und Circus: Der Palast von Konstantinopel und die religiöse Repräsentation Constantins des Großen. In: Joachim Ganzert and Irmgard Nielsen (ed.), Herrschaftsverhältnisse und Herrschaftslegitimation. Bau und Gartenkultur als historische Quellengattung hinsichtlich Manifestation und Legitimation von Herrschaft (Hephaistos. Sonderband 11), Berlin 2015, 129-140.

45 Sozom. hist. eccl. 1.5.1; Zos. 2.29.

46 E. g. Hartmut Leppin, Von Constantin dem Großen zu Theodosius II.: Das christliche Kaisertum bei den Kirchenhistorikern Socrates, Sozomenus und Theodoret (Hypomnemata 110), Göttingen 1996.

47 Mischa Meier, Das andere Zeitalter Justinians. Kontingenzerfahrung und Kontingenzbewältigung im 6. Jahrhundert n. Chr. (Hypomnemata 147), Göttingen 2003, 608-638.

48 Hartmut Leppin, George Pisides' Expeditio Persica and Discourses on Warfare in Late Antiquity. In: Anna Lefteratou and Fotini Hadjittofi (eds.), Generic Debates and Late Antique Christian Poetry. Between Modulations and Transpositions (Trends in Classics. Suppl. Vol. 86), Berlin/Boston 2020, 293-309. 


\section{Neutralising Discourses: The Case of Themistius}

Eusebius focused on Christian audiences. Most Roman panegyrists of the fourth century, however, gave speeches at the court, in the senate or before other public bodies and had to consider that their audiences were complex and religiously mixed. Thus, there were pagans and Christians whose degree of religious commitment differed within both of these groups. There were people whose identity was shaped by their religious position (for example bishops), others whose personal convictions were strong, but many who did not put religion centre stage and were more interested in their personal advancement and/or in the unity of the Roman Empire. Most of them would have avoided contacts with the Christian church and were pagans in that sense; but a growing number consisted of people who were at least open to Christian teachings (although only a tiny fraction would have been baptised). Religion was an important factor. But one should not take for granted that religion was the subject that shaped every discourse. Often this issue was sidestepped or simply regarded as less relevant. A neutralising discourse that avoided commitments to either side helped to reduce tension between Christians and pagans.

Significantly, the collection of Panegyrici Latini, which comprises 12 panegyrics, spans the time from Pliny's panegyric on Trajan (100) to Pacatus' speech on Theodosius (389). The collection was probably compiled in Gaul and seems to have served the purposes of rhetorical schools. Five speeches praise Constantine, three of them were composed before 312 (no. 5 in 311/2, no. 6 in 310, no. 7 in 307) and two afterwards (no. 12 in 313 and no. 4 in 321). The fact that the collection includes speeches from both before and after 312 demonstrates that rhetoricians did not feel that the Christianisation of imperial rule caused an unbridgeable gap.

In addition, given the diversity of the audience, there were good reasons to compose speeches that were neutral in terms of religion. Neutrality in the sense used here ${ }^{49}$ has an aspect of avoidance, but also includes certain concepts acceptable to both pagans and Christians. Avoidance means not addressing the building of either temples or churches or other acts that implied a clear religious commitment. When, for example, Themistius quoted the Hebrew Bible he referred to Assyrians,

49 On the concept of neutralisation, see Hartmut Leppin, Christianisierungen im Römischen Reich. In: ZAC 16 (2012) 245-276, especially 259-265. The term "neutralisation" goes back to Carl Schmitt, who, however, has a very critical stance on the subject. I interpret it as a means of creating peace in societies riddled with fundamental conflicts. However, I deliberately avoid Schmitt's term 'political theology,' which has spurred a long debate, since it seems too loaded with contemporary issues and does not take account of the nuances of political thinking in antiquity. Schmitt, Die europäische Kultur in Zwischenstadien der Neutralisierung. In: Europäische Revue 5.8 (1929) 517-530. For a recent overview, see Singh (cf. fn. 20). 
which was a classical as well as a neutral word (or. 7.89d; $11.147 \mathrm{~b} / \mathrm{c} ; 19.229 \mathrm{a}) .{ }^{50}$ On the other hand, ambiguous concepts, such as the praise of piety appealed to pagans and Christians alike; likewise, as mentioned before, philanthropy could be understood in both a general or specifically Christian sense.

To that effect, the Latin panegyrics claim Constantine was divinely protected, without elaborating on who this God/god was. They used general expressions in a vague monotheistic sense such as that force, that majesty that distinguishes right and wrong or this supreme majesty ${ }^{51}$ and extolled virtues acceptable to everybody such as accessibility, clemency, the ambition to win glory (which some Christians might have found disturbing). There are some more passages of which meticulous theologians would not have approved, but they were certainly not intended to be provocative.

It is curious to see how the panegyrists dealt with Constantine's victory at the Milvian Bridge, the event many Christians praised as being decisive for Constantine's conversion. As early as 313, an unknown orator dedicated a speech to this event (12[9]), especially $14-18) .^{52} \mathrm{He}$ makes clear that this victory was God-given, mostly dwelling on abstract religious expressions in respect to a single divinity. He mentions dii minores (2.5) and an abstraction such as Fortuna (2.5; 6.2; 15.6; 22.6). Nevertheless, Constantine's success is not based on his adherence to certain religious practices, but he has been selected by (a) god. Yet, there is no mention of a vision or of an intervention of the Christian God.

Nazarius' panegyric on Constantine, dated to 321 (4[10]) strives even harder to reach neutrality in its language. The speech discusses the Battle of the Milvian Bridge before the Roman Senate, an audience of which the majority would have been pagan, though not necessarily committed pagans..$^{53}$

It comes as no surprise that Nazarius extolls Constantine's military successes, among them his victory at the Milvian Bridge (27.5-30.3), which leads to the liberation of Rome. Nazarius' description of the battle centres on the military qualities of Constantine. He does not mention the intervention of any God/god, be they Christian or pagan. He speaks of the role of Fortuna (26.1) and mentions Mars (7.1) but leaves it up to the reader whether to understand this to mean a divinity or an abstract principle.

I do not think it is helpful to speculate on whether or not Nazarius was a Christian. On the one hand, there were many variations of more or less committed forms of

50 For a possible allusion to Christian theology in or. 1.8b, see Michael Schramm, Freundschaft im Neuplatonismus. Politisches Denken und Sozialphilosophie von Plotin bis Kaiser Julian, Berlin/Boston 2013, $201 \mathrm{f}$.

51 Pan. Lat. 4(10).7.4: illa vis, illa maiestas fandi et nefandi discriminatrix (taking up Verg., Aen. 1.543); 4(10).16.1: summa illa maiestas.

52 Christian Ronning, Herrscherpanegyrik unter Trajan und Konstantin (Studien zu Antike und Christentum 42), Tübingen 2007, 291-379; Wienand (cf. fn. 16) 246-253.

53 On this speech and its political background, see Wienand (cf. fn. 16) 281-287. 
Christianity; on the other, Nazarius had to take his audience into account, which consisted of both Christians and non-Christians. Using a neutralising language was the most obvious way to navigate this course.

The avoidance of religious commitments in panegyric texts is part of a wider phenomenon of neutralisation in the fourth century Roman Empire. In this context, I am focusing on political connotations as they were a general feature of imperial representation, but neutralisation also affected the perception of the intellectual tradition of the Mediterranean world. ${ }^{54}$

Themistius (ca. 317-after 388), perhaps the most famous orator of his age, embodies an attitude that brought together loyalty and neutrality. He celebrated emperors in religious semantics but circumvented concepts that were either specifically Christian or specifically pagan. The philosopher-rhetorician has perplexed many scholars. He was a pagan but served Christian emperors loyally and did his best to praise their achievements without directly mentioning their efforts to foster Christianity - which were, however, crucial from the perspective of many Christian authors. Themistius was a highly educated Grecophone author based in Constantinople. ${ }^{55}$ Like many philosophers of his time, he set out to harmonise Aristotelian and Platonic philosophical concepts. His paraphrases of Aristotle's works were translated into Latin, Hebrew and Arabic. ${ }^{56}$

Another significant portion of his oeuvre is made up of his orations, among them a group called the political orations because they were intended to be performed before political institutions. Eighteen political orations have been transmitted ${ }^{57}$ - they praise Constantius II, Jovian, Valens, Valentinian, Gratian, and Theodosius. Although it is difficult to gauge to what degree they have been edited, there is no doubt that they are close to the original since they were clearly tailored to specific historical circumstances.

All the emperors were Christians, but Themistius was able to glorify them without relying on specifically Christian concepts. No oration of his on Julian is attested

54 As a locus classicus, see Greg. Nyss., Mos. 2.112-115.

55 John Vanderspoel, Themistius and the Imperial Court, Ann Arbor 1995; Peter J. Heather, Themistius: A Political Philosopher. In: Mary Whitby (ed.): The Propaganda of Power. The Role of Panegyric in Late Antiquity, Leiden 1998, 125-150. Robert M. Errington, Themistius and His Emperors. In: Chiron 30 (2000) 861-904. For the philosophical context, see Schramm (cf. fn. 50) 182-299, especially $200-228$. Dvornik (cf. fn. 7) 622-626 sees the Hellenistic influence as the common denominator between Eusebius and Themistius. The fact that Themistius does not mention minor gods betrays Christian influence in his view (626).

56 For translations and transmissions, see Aburrahmān Badawi, La transmission de la philosophie grecque au monde arabe, Paris 1987, 115-117; Robert B. Todd, Themistius. In: Virginia Brown (ed.), Catalogus translationum et commentariorum: Mediaeval and Renaissance Latin Translations and Commentaries, Bd. 8, Washington, D.C. 2003, 57-102.

57 Numbered as or. 1-11; 13-19. The 12th is an early modern forgery. 
with certainty, ${ }^{58}$ which is remarkable since Themistius exchanged letters with Julian and certainly did not oppose him. He may have abhorred the emperor's uncompromising stance towards Christianity and his Neoplatonic philosophy, but perhaps he simply lacked the opportunity to give a speech on Julian who spent only a few months in Constantinople during his brief reign. It could also be a matter of transmission.

In many regards Themistius' speeches follow the tradition of earlier orators, such as Dio Chrysostom and Aelius Aristides who discussed ideas of good kingship, and draws upon the rules for panegyrics known from Menander Rhetor. Themistius has often been condemned as an opportunistic flatterer, which is an anachronistic judgement given his function as an official orator. But he certainly adapted to the requirements of individual rulers. Therefore, each of his orations retains its own character.

Nevertheless, he sticks to certain philosophical concepts, which he hammers home to his audiences again and again. The emperor is encouraged to demonstrate by his rule that he is imitating God, who has chosen him, even assimilating himself to God through his virtues. Although in contrast to God he is not eternal and does not

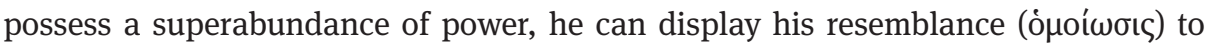
God:

But virtue towards mankind, gentleness and goodwill...are those not much more accessible for him who shares in our common nature? For this is what makes him godlike, this is what makes him divine; it is thus that a king becomes divinely nourished, thus divinely born, and we will not be lying when we attribute divinity to him on these terms. ${ }^{59}$

In this way, the emperor can be described as a reflection of the peaceful well-ordered cosmic rule of God. ${ }^{60}$

An important neutralising concept is the idea of philanthropy, which was a core value of late antique rulership. In Themistius' view it was mainly this virtue that connected humanity, especially the emperor, and God. ${ }^{61}$ Philanthropy was a royal virtue early on and was highlighted by Hellenistic philosophers. This concept could be understood in the sense of Christian charity as well as in the tradition of Roman clementia. Other aspects include that rulers are invested with their power by God and em-

58 On the Risâlat (which is only preserved in two Arabic manuscripts) as a speech of Themistius for Julian, see Vanderspoel (cf. fn. 55) 115-134; 241-249.

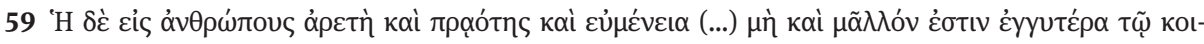

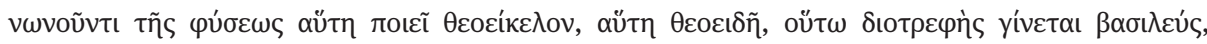

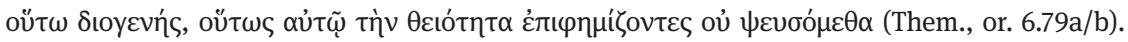

60 In her dissertation, Simone Mehr (Frankfurt am Main) will show in detail how Themistius addresses individual issues within the imperial political platform as proof of the emperor's divine legitimisation.

61 Boris Maslov, The Limits of Platonism. Gregory of Nazianzus and the Invention of theōsis. In: GRBS 52 (2012) 460 - 468, especially 466-468. See also Schramm (cf. fn. 50) 211-228. 


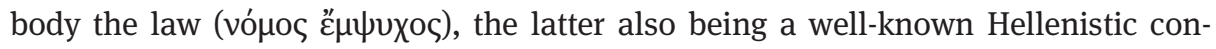
cept. In later orations, Themistius alludes to biblical passages but in passing side by side with quotations from Plato and Aristotle. He certainly did not define the Bible as the most authoritative text as Christians would have. In contrast to Neoplatonic thinkers of his time, he sees the active involvement of philosophers teaching their audiences about imperial virtues in politics as crucial - they are, however, surpassed by the emperor who can actively make a difference and is closest to God. ${ }^{62}$

As an illustration of his attitude I will discuss the fifth oration, perhaps his most famous work since it pleads for forbearance with deviant religious attitudes. ${ }^{63}$ In this speech, Themistius addresses Jovian who had come to power under difficult circumstances. When Julian, his predecessor, died in Persia, the troops acclaimed the new emperor unexpectedly. Ammianus even suggests that some hailed him erroneously, because of the similarity of his name with Julian's (25.5.6). He had to come to terms with Persia (which entailed territorial losses) in order to safely lead his troops back to the Roman Empire, which was afflicted with religious conflicts. Representatives of the conflicting parties streamed to the new emperor in the hope of winning him over to their concerns. On the 1st of January 364, while he was in Ancyra, Jovian assumed the office of the consul together with his infant son Varronianus. This was the occasion for which Themistius gave his oration.

The panegyric starts in a way typical of Themistius, underlining from the first paragraph the importance of philosophy for good rulership. During the festivities for a consulship the task of the philosopher is not to entertain the audience, but to contribute something useful, albeit in a pleasing manner. Jovian is a worthy emperor since he has decided to restore philosophy to the palace once more. Thus, Themistius duly starts his counselling, underlining that the emperor embodies the law and what this implies:

(The philosophy) declares that the king is law embodied, a divine law which has come down from on high at last, an outpouring of the everlasting Good, a providence of that nature closer to the earth, (a law) which looks in every way towards Him (God) and strives in every way for imitation. ${ }^{64}$

62 O’Meara (cf. fn. 16) 206-208. There was another line of philosophy at his time that relied on theurgic practices. Its importance to Themistius will be demonstrated in detail by Simone Mehr. For a foundational study on pagan identities in late antiquity, see Jan Stenger, Hellenische Identität in der Spätantike: Pagane Autoren und ihr Unbehagen an der eigenen Zeit (UALG 97), Berlin 2009.

63 Vanderspoel (cf. fn. 55) 138-154; Stenger (cf. fn. 62) 371-377; Hubert Cancik and Hildegard Cancik-Lindemaier, Religionsfreiheit und Individualisierung von Religion. In: Martin Wallraff (ed.), Religiöse Toleranz. 1700 Jahre nach dem Edikt von Mailand (Colloquium Rauricum 14), Berlin 2016, 193 222; Peter van Nuffelen, Penser la tolérance dans l'Antiquité tardive, Paris 2018, especially 57-59.

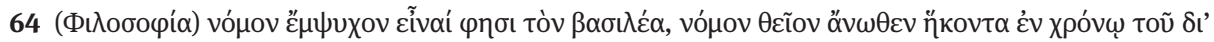

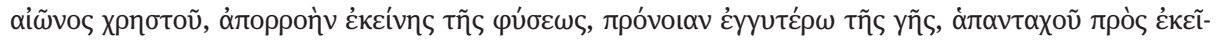

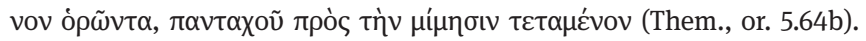


This passage is full of Neoplatonic semantics and therefore deeply embedded in a non-Christian (and in that sense pagan) tradition. However, it is articulated in such an abstract way that most Christians could accept it as an adequate description of a ruler trusting in God and invested by God. Themistius praises the circumstances of Jovian's election and does not conceal how unexpected his ascension to the throne was. From Constantine to Julian, dynastic succession had prevailed. Therefore, Jovian's elevation to the throne was a significant break. But Themistius defines him as a dynastic relative in soul and therefore as a worthy successor as he excels in virtue: "But our voters and soldiers preferred spiritual to physical kinship and declared as heir to the imperial purple the heir of his virtue"65. Even the Persians were impressed and threw away their weapons as a sign that the Romans had elected the best emperor - East and West concurred in deeming him the rightful Roman emperor. He proved himself worthy of the task as he took an office that was "unstained

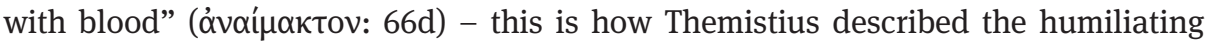
peace treaty he made with the Persians, which had been concluded without acts of violence thanks to Roman concessions. Another point of praise is Jovian's generosity to his former comrades whom he does not treat arrogantly. He also makes a good choice of courtiers.

But the longest passage is dedicated to his policy of forbearance. It starts on a high semantic and intellectual level:

Hence your legislation on the divine has become a prelude for your care for mankind. And now my speech has arrived at the point of departure to which I have long been tending. For it seems that you alone are not unaware that a king cannot compel his subjects in everything, but that there are some matters which have escaped compulsion and are superior to threat and injunction, for example the whole question of virtue and, above all, reverence for the divine and that it is necessary for whoever intends that they should exist naturally to take the lead in these good things, having realised most wisely that the impulse of the soul is unconstrained, and is both autonomous and voluntary. ${ }^{66}$

Themistius puts forward various reasons for his conviction. Jovian knows that he cannot compel his subjects when it comes to religion. Another argument is that competition between religions is beneficial; he compares religious diversity with a race to one arbiter (68d). Jovian follows Plato's legislation in allowing traditional cults to be observed and prohibiting magical practices. At the end of the speech the orator makes a slightly detracting remark: Themistius deplores that the festivities for the

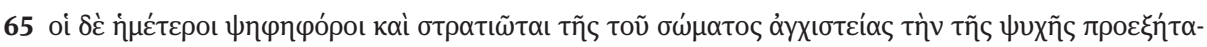

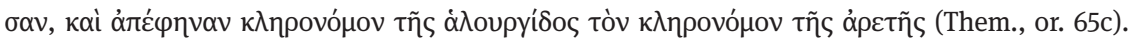

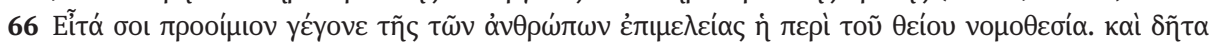

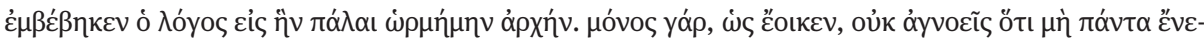

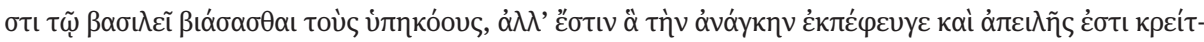

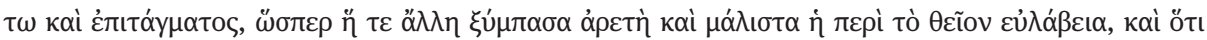

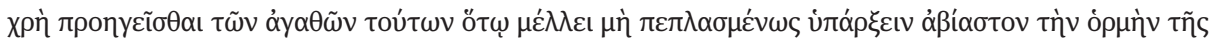

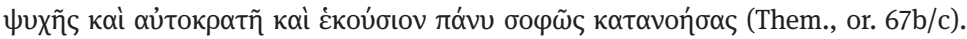


consulship do not take place in Constantinople. This is a common theme in Themistius' works and criticising the emperor in this aspect was part of the game; nobody could take offense if Themistius did so as a local representative. At this time, it was reasonable to expect Jovian to arrive in Constantinople soon - nobody could foresee his sudden death caused by the poisonous fumes of a warming fire.

Other orations by Themistius add further imperial virtues and achievements: self-control, education, mildness even towards offenders, generosity (which can materialise in tax-reductions as in or. 8), and justice. Only the incessant claim that the emperor should show interest in the affairs of Constantinople is a more parochial element of Themistius' rhetoric, for obvious reasons.

As mentioned before, Themistius was able to adjust his manner of praise according to his subject. Constantius II, for example, appears to be a philosopher on the throne (especially or. 1). It would have come as a real surprise to the audience if Themistius had ascribed education to Valens who had a rural and military background; nonetheless, Themistius underlines his respect for philosophy (or. 6) and describes him as a practitioner of philosophy (or. 9). In a sense, emperors were better philosophers than Themistius could be as he says modestly. They had better opportunities to enact their philosophy in active life, which Themistius preferred to mere contemplation (which, however, took precedence for many Neoplatonists). ${ }^{67}$

Military victory against domestic and foreign enemies is praised repeatedly, even more so peaceful victories, like Vetranio's renunciation of power in the time of Constantius (or. 2-4) or Theodosius' treaty with the Goths who had invaded the Roman Empire and were permitted to settle there (or. 16). Barbarians should be convinced to become loyal subjects of the emperor, not killed (or. 10; 15). This attitude ties in well with the praise of Jovian for his peace treaty - it is obvious that a panegyrist such as Themistius was closer to administrative than to military elites. He knew how to face special challenges. The eighth oration underlines not only the importance of brotherly love between the siblings Valens and Valentinian but also reforms in taxation. He duly praised military successes, but still more peace treaties (or. 16). And he does not mention any event comparable to Constantine's victory at the Milvian Bridge that was interpreted as the decisive step to Christian rule.

None of the virtues extolled by Themistius were offensive to Christians or pagans. There is, however, no passage in which Themistius praises the emperors for their support of the Christian religion or their fight against paganism. This aspect is obviously side-stepped. Every thought, every argument in Themistius' writings is shaped by what he deems philosophy. ${ }^{68}$ His philosophy is rooted in the classical tradition and draws on classical concepts of virtue. Yet, he defines the corresponding values in a way that was acceptable, even familiar to many Christians, especially

67 For the distance between Themistius and Neoplatonic philosophers, see O'Meara (cf. fn. 16) 207. 68 Simone Mehr will explore this in more detail in her doctoral dissertation. 
to those who had devised a theology imbued with Platonic concepts. Thus, Christians could be depicted as philosophers, at least in practice.

Themistius, the pagan orator at Christian courts, was a virtuoso in using neutralising discourses. The passages on forbearance in his fifth oration can be read as justifications of a neutralising attitude which does not force anybody into dishonest confessions and allows for the free competition of ideas. This seems to have been the emperor's attitude at a time when he was not strong enough to disappoint any group and when many inhabitants of the Roman Empire were disaffected by Julian's partisan policy. Perhaps most importantly for the ruling classes, this attitude dodged conflicts. It comes as no surprise that this justification was not very influential in its time since neutralisation was the result of a compromise and took shape as a set of practices. Although the influence of Stoic thinking about individual liberty is visible, this policy was not the result of political theorising or the consequence of certain values highlighting human dignity, as is the case with the idea of tolerance in modern times. ${ }^{69}$ This is the only oration in which Themistius explicitly sets out to (indirectly) justify the neutralising discourse he uses in all his political speeches. It remains an almost isolated case.

Themistius was a master in ambiguity and thus able to use Platonic and Aristotelian concepts of good rulership without offending his Christian audience. He was not the only orator who followed those lines. Libanius' 59th oration, probably of 344/ 5 during the co-rulership of Constans and Constantius II, steers clear of any religious commitments although it alludes to the consequences of confessional conflicts. ${ }^{70} \mathrm{He}$ is considerably more aggressive against Christians in other speeches such as in his Julianic orations $(12-18 ; 24)$ and his Pro templis. ${ }^{71}$ The panegyrics composed by Julian as crown prince on Constantius II and on Eusebia point in a more neutralising direction. ${ }^{72}$ While the first speech is very formal, ${ }^{73}$ the second (viz. third) speech con-

69 A similar idea occurs in Symm., relat. 3.8, but he argues not from a philosophical standpoint, but from a historical and religious one. For more detail, see Cancik and Cancik-Lindemeier (cf. fn. 63 ) 216. 70 For the date, see Werner Portmann, Die 59. Rede des Libanios und das Datum der Schlacht von Singara. In: BZ 82 (1989) 1-18; Karin Mosig-Walburg, Zur Schlacht bei Singara. In: Historia 48 (1999), 330 - 384. The suppression of mantic practices as praised in $\S 167$ might be viewed as a religious measure but is not interpreted as antipagan by Libanius.

71 Lieve Van Hoof (ed.), Libanius: A Critical Introduction. Cambridge 2014, especially Hans-Ulrich Wiemer, Emperors and Empire in Libanius, 187-219; Heinz-Günther Nesselrath et al. (ed.), Für Religionsfreiheit, Recht und Toleranz. Libanios' Rede für den Erhalt der heidnischen Tempel. Eingeleitet, übersetzt und mit interpretierenden Essays versehen, Tübingen 2011.

72 Klaus Bringmann, Kaiser Julian. Der letzte heidnische Herrscher, Darmstadt 2004, 49-52; Stenger (cf. fn. 62) 140-152. See also Schramm (cf. fn. 50) 300-443. On the contributions on the individual speeches, see Nicholas Baker-Brian and Shaun Tougher (ed.), Emperor and Author. The Writings of Julian the Apostate, Swansea 2012: Shaun Tougher, Reading between the Lines: Julian's First Pangyric on Constantius II., 19-34; Hal A. Drake, 'But I digress...' Rhetoric and Propaganda in Julian's Second Oration to Constantius, 35-46; Liz James, Is there an Empress in the Text? Julian's Speech of Thanks to Eusebia, 47-59. 
forms much less to rhetorical rules and seems to exhort the emperor using very general terms to not neglect the cult of gods (86a). This should not be taken as a clear indication of Julian's paganism; whether this speech was given in public remains to be answered..$^{74}$ Like Themistius, Julian performs the role of a philosopher on this occasion and like him, he does not mention Christianity. He had not yet revealed his pagan convictions at this time, but this rhetorical tradition must have appealed to him.

At the turn of the century, Synesius of Cyrene (who would later become bishop) avoided a clear religious commitment in his speech Peri basileias, which unmistakeably betrays Themistius' influence. This text exhorts Emperor Arcadius (395-408) to return to Roman traditions of military prowess and to suppress the influence of barbarians. The orator argues with unusual frankness using the literary guise of a panegyric. It was probably not delivered before the emperor but possibly to another audience. ${ }^{75}$ Even in the time of Justinian, writers such as Agapetus and the author of the Dialogue on Political Science can be seen as upholding a neutralising tradition. Although some hints at Christianity may be heard, such as quotations of Psalm 111 (110):10 or Proverbs 1:7 in Agapetus 17, the works are dominated by a Platonising tradition. ${ }^{76}$ But these were exceptions. Most concepts of rulership put Jewish-Christian traditions centre stage. It must therefore have been a conscious decision to stick with a tradition that was not specifically Christian but could be easily accepted in an educated Christian context.

73 Alan J. Ross, The Constantinians' Return to the West. Julian's Depiction of Constantius II in Oration I. In: Diederik Burgersdijk and Alan J. Ross (ed.), Imagining Emperors in the Later Roman Empire (Cultural Interactions in the Mediterranean 1), Leiden/Boston 2018, 183-203 interprets this speech as a revision of Libanius' account.

74 Stefan Schorn, Legitimation und Sicherung von Herrschaft durch Kritik am Kaiser. Zum sogenannten zweiten Panegyrikos Julians auf Kaiser Constantius (or. 2 [3] Bidez) (243-274). In: Thomas Baier (ed.), Die Legitimation der Einzelherrschaft im Kontext der Generationenthematik (Beiträge zur Altertumskunde 251), Berlin 2008, 243-274 argues that Julian planned to integrate pagan elites with this approach. On the debate of the seriousness of the oration, see Schramm (cf. fn. 50) 359f. On the possibility of a parody, see Drake (cf. fn. 72). Stenger (cf. fn. 62) 142-147 interprets the Homeric allusions as subversive in themselves.

75 Alan Cameron and Jacqueline Long, Barbarians and Politics at the Court of Arcadius, Berkeley 1993 are doubtful. For an argument in favour of a select private audience, see Alexander Petkas, The King in Words: Performance and Fiction in Synesius De Regno. In: AJPh 139 (2018) 123-151. On a performance before the emperor, see Hartwin Brandt, Die Rede peri basileias des Synesios von Kyrene - ein ungewöhnlicher Fürstenspiegel. In: François Chausson and Etienne Wolff (ed.), Consuetudinis amor. Fragments d'histoire romaine (IIe-VIe siecles) offerts à Jean-Pierre Callu (Saggi di storia antica, 19), Rome 2003, 57-70.

76 Patrick Henry III, A Mirror for Justinian. In: GRBS 8 (1967), 281-308; O’Meara (cf. fn. 16) 171f.; Peter N. Bell (ed. and transl.), Three Political Voices from the Age of Justinian, Liverpool 2009. O'Meara rightly states that there is little Platonic philosophy in a rigid sense in the text but the philosophical attitude is similar to that of Themistius. 


\section{Go-Betweens, Saints and Sinners: Conclusions and Outlook}

The fourth century was an age of experiments. Christians and non-Christians pondered about how to cope with the unexpected advent of a Christian emperor. The rulers themselves were forced to decide what being a Christian meant to their personal behaviour; Constantius II, by the way, seems to have taken this much more earnestly than Constantine. Christian Roman officials had to decide to what degree they were obliged to fight paganism - under Theodosius (379-395) the legislation became much tougher although in practice it seems to have been relatively mild. They had to ask themselves to what degree they would side with one of the confessional groups and which role synods should play. In addition (and certainly more importantly), they waged wars against domestic rivals, but also against foreign enemies. They had to deal with economic problems, collect taxes, issue laws, and dispense justice in the Empire. Every single emperor differed in their approach to Christian rulership. Julian (361-363), in fact, decided to demonstratively act as a non-Christian ruler although his rulership exhibited many Christian influences.

This ever-changing situation made it even more difficult for panegyrists to fulfil their task. They drew on various sources in praising the ruler, they took different ideological stances, and they had to react to the more or less explicit demands of individual rulers. Therefore, acclaiming the good Christian ruler must have been anything but monotonous.

In order to chart the map, I have drawn a heuristic distinction between neutralising and hierocratic discourses on the praise of imperial rule during the fourth century. Whereas the former avoided religious commitments and was intended to appeal to Christians and non-Christians alike, the latter extolled the person of the emperor in view of Christian concepts. There was, however, no unitarian Christian concept of rulership. Even within the works of a single author, such as Eusebius, many differences are visible despite having certain semantics in common regarding the traditional virtues of the emperor. Consequently, they made use of certain ambiguous 'buzzwords,' among which philanthropy is probably the most important. With all their religious and ideological differences, Christians and pagans had a common cause, which went beyond identifying with the Roman Empire against foreign enemies and included basic values that were not only based on paideia.

As I have said, Christian discourses could vary considerably. The extreme form would have been a Christocentric discourse that identified the emperor with Christ, which was rare. By way of contrast, the idea of the emperor as the perfect embodiment of virtues was extremely popular. It included traditional as well as Christian virtues, while some Christian virtues for their part could easily be identified with the traditional ones. This distinction can therefore only be heuristic. The Christianising discourse did not exclude the possibility of the well-intentioned Christian emperor making mistakes or even experiencing defeat. The penitential discourse even put 
humility centre stage, and this had an important consequence in terms of authority. Doing penance meant accepting the bishop's pastoral responsibility as Theodosius had to accept Ambrose's role as intermediator between himself and God. ${ }^{77}$

An important feature in the development of the idea of rulership was criticism of the ruler, especially of perceived heretical ones. Authors could resort to invective as taught by rhetoricians; in addition, the Old Testament provided rich material in this regard. The Latin author Lucifer of Cagliari, a sharp critic of Constantius II, was perhaps the most aggressive user of this rich source of antagonistic language. ${ }^{78}$ Ex negativo, critical remarks could not but enrich the discourse on the good ruler.

The fourth century left a complex heritage. Although Christianity became ever more important at this time, there was no linear development. Even neutralising discourses survived throughout late antiquity as we have seen, and Christocentric discourse could be rejuvenated. Nor was there one dominant Christian discourse; nevertheless, Christian discourses became predominant and a growing number of Christian authorities were inclined to disambiguate such concepts as philanthropy in order to give them a specifically Christian meaning. This volume demonstrates that Christianity prompted many more discourses, which are part of the polyphony of late antique Christianity.

77 See Boytsov and Preuß in this volume.

78 Walter Tietze, Lucifer von Calaris und die Kirchenpolitik des Constantius II: Zum Konflikt zwischen dem Kaiser Constantius II. und der nikänisch-orthodoxen Opposition (Lucifer von Calaris, Athanasius von Alexandria, Hilarius von Poitiers, Ossius von Córdoba, Liberius von Rom und Eusebius von Vercelli), Diss. Tübingen 1976, 82-76; Javier Pérez Mas, La crisis luciferiana: un intento de reconstrucción histórica, Rome 2008, 142-148. 
